\title{
Effect of UV Light on Secondary Metabolite Biosynthesis in Plant Cell Cultures Elicited with Cyclodextrins and Methyl Jasmonate
}

\author{
Lorena Almagro, Ana Belén Sabater-Jara, Sarai Belchí-Navarro, \\ Francisco Fernández-Pérez, Roque Bru and María A. Pedreño \\ University of Murcia \\ Spain
}

\section{Introduction}

All the chemical reactions that occur in the cells of a living organism are called metabolism. By these reactions, a large number of organic compounds, including sugars, amino acids, fatty acids, nucleotides and their polymers derived, that is, polysaccharides, proteins, lipids, RNA, DNA, etc ... are produced. These processes are essential and common to all organisms and are known as primary metabolism and related compounds are known as primary metabolites. In the case of plants, in addition to the primary metabolic pathways, other metabolic pathways are activated under certain situations and the compounds produced are called secondary metabolites. The role of secondary metabolites may seem irrelevant, but the truth is that the plant spends a great deal of energy in their synthesis and they have remained in the plant kingdom up to date. This is because that wide variety and high diversity of secondary metabolites have apparently evolved as a means for plants to interact with the environment and for the development of resistance against both abiotic and biotic stress. In fact, secondary metabolites are useful to protect plants against herbivores (insects and vertebrates), mammals, bacteria, fungi, viruses and even other competing plants. In addition, some plants use secondary metabolites to attract pollinators and seed dispersers, as signals for communication between plants and symbiotic microorganisms or for protection against UV light and other physical stress (Wink 2003, 2008).

Daucus carota L. (Umbelliferae) is a biennial herb, whose fruits (common name: wild carrot fruits) have been used in traditional Chinese medicine for the treatment of ancylostomiasis, dropsy, chronic kidney disease and bladder afflictions (Pant \& Manandhar, 2007) due to a wide range of reported pharmacological effects, including antibacterial (Rossi et al., 2007), antifungal (Tavares et al., 2008), antihelminthic, hepatoprotective (Bishayee et al., 1995) and cytotoxic activities (Yang et al., 2008; Fu et al., 2009). Carrot roots contain a variety of carotenoids and anthocyanins that are responsible for the typical colour of the root. In addition, this vegetable also produces phenolic compounds such as scopoletin, $p$-hydroxy benzoic acid and the isocoumarin, 6-methoxymellein, all major components of the phytoalexin complex (Mercier et al., 2000). These compounds are induced in carrot by fungal infection, heavy metals or UV light (Marinelli et al., 1994), and therefore they are involved in plant defence responses. Recently, Sabater-Jara et al., (2008) have described the production of sterols in different cell cultures including D. carota. 
Plant sterols, also called phytosterols, are isoprenoid-derived lipids that play essential roles in plant growth and development since they are integral components of the plant cell membranes and are responsible for its permeability and fluidity (Posé et al., 2009). In addition, phytosterols play an important role in cellular processes as precursors for brassinosteroids biosynthesis. They are also components of a wide variety of secondary metabolites such as the glycoalkaloids, cardenolides and saponins. Moreover, phytosterols have important pharmacological activities, including cholesterol-lowering, antitumor effects against lung, stomach, ovary and estrogen-dependent human breast cancer (Woyengo et al., 2009) and recently, they have reported to exert anti-atherosclerotic, anti-inflammatory and anti-oxidative activities in animals (Delgado-Zamarreño et al., 2009). The beneficial health effects of phytosterols have led to search potential strategies for enhancement these compounds from other natural sources. In this sense, the use of plant cell cultures has been developed as a promising alternative, especially when the production of bioactive compounds is difficult or unprofitable, or when it involves serious damage to the environment. In this way, campesterol, stigmasterol, $\beta$-sitosterol and fucosterol (Fig. 1), being major phytosterols found in plants, have been recently produced using plant cell systems (Sabater-Jara et al., 2010a,b; Bonfill et al., 2011; Lee et al., 2004 and Herchi et al., 2009).

A

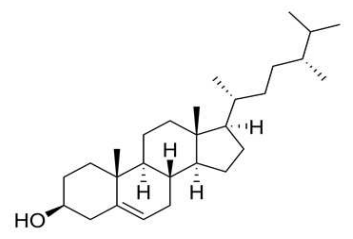

C

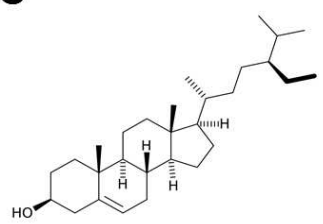

B

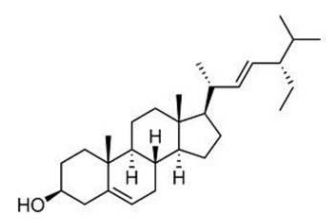

D

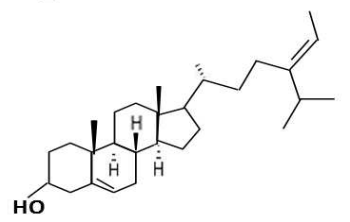

Fig. 1. Structures of Campesterol(A), Stigmasterol (B), $\beta$-Sitosterol (C), and Fucosterol (D).

Catharanthus roseus (Madagascar periwinkle) is a perennial tropical plant belonging to the family Apocynaceae that produces more than 130 alkaloids (van der Heijden et al., 2004). The importance of this plant relies in its ability to synthesize a wide range of terpenoid indole alkaloids as part of its secondary metabolism. These compounds have vital roles as mediators of ecological interactions, and are very important for plant survival. They are involved in the defense against competitors, herbivores and pathogens, in attracting pollinators or symbionts and in the adaptation to both biotic and abiotic stress conditions. Although they are constitutive compounds, their levels may be enhanced by several factors. Some terpenoid indole alkaloids have a high added value because of their broad spectrum of pharmacological applications. Special attention has focused on the production of the antihypertensive monomeric terpenoid indole alkaloids serpentine and ajmalicine (Fig. 2A), which are used to combat heart arrhythmias and to improve the blood circulation in 
the brain (Asada \& Shuler, 1989). The dimeric terpenoid indole alkaloids, 3',4'anhydrovinblastine, vincristine, and vinblastine have powerful effects as anticancer drugs (Zhou et al., 2009). These dimeric terpenoid indole alkaloids are synthesized from vindoline and catharanthine (Fig. 2B). Catharanthine can be chemically coupled with vindoline to form the clinically important anticancer drug, vinblastine and so this could provide a novel and efficient way to produce vinblastine commercially. Vindoline is abundant in C. roseus plants, and catharanthine can be produced by C. roseus cell or hairy root cultures (Zhao et al., 2001), so a combination of both pathways could lead to a very high vinblastine production. Therefore, the production of catharanthine by various $C$. roseus cell types in culture and its mechanism of biosynthesis has been one of most extensively explored areas of plant cell or hairy root cultures in recent years. In this sense, the application of biotic or abiotic stimuli has been one of the most effective strategies for improving the productivity of terpenoid indole alkaloids from C. roseus cell cultures (Zhao et al., 2000).

Vitis vinifera produces stilbenes, which are a small group of compounds characterized by a 1,2-diphenylethylene backbone, derived from the phenylpropanoid pathway. Most plant stilbenes have phytoalexin activity and are derivatives of the monomeric unit transresveratrol (3,5,4'-trihydroxystilbene, Fig. 2C) although other structures are found in other plant families. In grape berries, stilbenes are synthesized under natural environmental conditions (Jeandet et al., 1991; Versari et al., 2001). The cis- and trans-isomers of resveratrol are mainly accumulated in the exocarp (skin) during all stages of development and are almost totally absent from pericarp (flesh). Monomers and oligomers of resveratrol are also constitutively present in the lignified organs of grapevine such as stems and roots (Jeandet et al., 2002). Therefore, both pre-existing high contents of stilbenes in plants and those synthesized after microbial attack are part of both constitutive and inducible defence responses. In addition to the well-known function of stilbenes as phytoalexins, these compounds may also be involved as chemical signals in allelopathy (Seigler et al., 2006), or in response to oxidative stress generated by UV irradiation (He et al., 2008; Privat et al., 2002; Teguo et al., 1998). The formation of stilbenes (namely viniferins in Vitis) is therefore considered to be a part of the general defense mechanisms since they also display strong antifungal and antimicrobial activities (Bru et al., 2006; Pezet et al., 2004; Morales et al., 1998). In fact, trans-resveratrol, is found in both grapevine tissue and berries, and in cell cultures as the result of both abiotic and biotic stress (Pezet et al., 2003, 2004; Cantos et al., 2003).

Since trans-resveratrol was postulated to be involved in the health benefits associated with a moderate consumption of red wine (Siemann \& Creasy, 1992), it is one of the most extensively studied natural products.

A

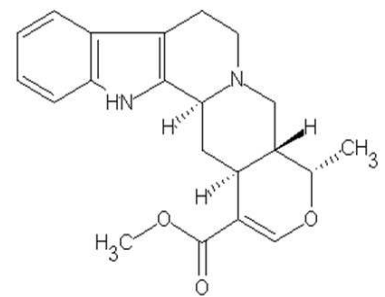

B

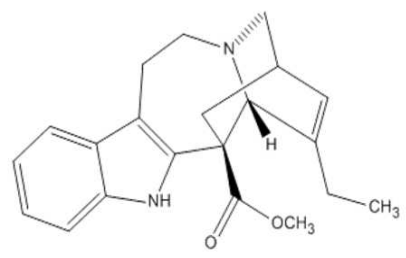

C<smiles>Oc1ccc(/C=C/c2cc(O)cc(O)c2)cc1</smiles>

Fig. 2. Structures of ajmalicine (A), catharanthine (B) and trans-resveratrol (C). 
Over the last 15 years, stilbenes, especially trans-resveratrol has received considerable interest, due to their biological activities and possible pharmacological applications. Hundreds of studies have reported the beneficial effects of trans-resveratrol on neurological (Okawara et al., 2007) and cardiovascular systems (Bradamante et al., 2004). One of the most striking biological activities of trans-resveratrol investigated during recent years has been its anticancer activity and it has been seen to prevent carcinogenesis in the stages of tumour initiation, promotion and progression (Pervaiz, 2003; Pezzuto, 2008). More results provide interesting insights into the effect of this compound on the lifespan of yeast, worms and flies, suggesting that trans-resveratrol could be regarded as a potential antiaging agent in treating age-related human diseases (De la Lastra \& Villegas, 2005). In addition, effects described in mice subjected to a high-calorie diet (Baur et al., 2006) point to new approaches for treating not only age-related diseases but also obesity-related disorders (Kaeberlein \& Rabinovitch, 2006). For these reasons, the wide ranging of pharmacological and clinical potential applications of trans-resveratrol and other stilbenes have been recently reviewed (Pezzuto, 2008; Shakibaei et al., 2009; Espín et al., 2007). That is why new strategies based on the use of $V$. vinifera cell cultures have been used to increase the level of trans-resveratrol production.

The close relationship between plant secondary metabolism and defence response is widely recognized. Plants not only respond to attack of pathogens, insects and herbivores or to other biotic and abiotic stresses but also to small molecules of different origin, called elicitors that trigger the same response in the plant as the pathogen or organism itself. When introduced in a living cell in small concentrations, elicitors are capable of redirecting the metabolism, leading to increased production of particular secondary metabolites. Then, elicitors are useful tools for improving the production of plant valuable secondary metabolites. In general, elicitors are classified on the basis of their origin and molecular structure. Biotic elicitors are derived from the pathogen or from the plant and can have a defined composition, when their molecular structures are known, or have a complex composition when they comprise several different molecular classes making impossible to define a unique chemical identity. On the other hand, abiotic elicitors have not a biological origin and are grouped in physical and chemicals factors (Vasconsuelo \& Boland, 2007).

A wide array of external stimuli are capable of triggering changes in the plant cell, leading to a cascade of reactions that ultimately result in the formation and accumulation of secondary metabolites, which help plants to overcome the stress factors. Amongst these, ultraviolet (UV) light which is a minor part of the solar spectrum, represents an important ecological factor that influences the organisms and ecosystems, and it is related to the occurrence of some adaptive changes in organisms throughout the development of life on Earth.

UV radiation is divided into three regions: UV-C (wavelengths below $280 \mathrm{~nm}$ ), UV-B (280$315 \mathrm{~nm}$ ) and UV-A (315-400 nm). UV-C is the most damaging, but it is almost completely absorbed by the stratosphere. By contrast, UV-B radiation is only partially absorbed by the stratospheric ozone layer, and UV-A is not absorbed at all. Therefore, a fraction of UV-B and all UV-A reaches the earth's surface, where they cause various biological effects. Moreover, the effectiveness of biological responses to UV radiation increases with decreasing wavelength, so these responses are normally dominated by the UV-B. However, in recent years UV-A action spectra have also been considered. 
Accumulation of UV-absorbing compounds, mainly those of phenolic nature, is a typical defense mechanism of plants to increased UV radiation, and is the most common response produced by vascular plants (Searles et al., 2001). Derivatives of hydroxycinnamic acid are UV-absorbing compounds which have received less attention, probably because they have been considered as constitutive, rather than inducible, protective barrier, against UV-B radiation (Bornman et al., 1997). However, they absorb UV-B more effectively than flavonoids, the other UV-absorbing compounds, whose absorption peaks are shifted to the UV-A radiation. As a result, derivatives of hydroxycinnamic acid may provide greater attenuation of UV-B radiation than flavonoids (Sheahan, 1996).

In plant cell cultures, UV light acts as an abiotic factor which stimulates the biosynthesis of secondary metabolites (Broeckling et al., 2005). Thus, it has been shown that UV-B light induces both the formation of dimeric terpenoid indole alkaloids and tryptophan decarboxylase and strictosidine synthase mRNA accumulation in C. roseus (Ouwerkek et al., 1999). Ramani \& Jayabaskaran (2008) also observed the enhanced production of catharanthine and vindoline from $C$. roseus cell cultures, when cells were irradiated with UV-B for 5 min. In a similar way, Gläßgen et al., (1998) studied the effect of continuous irradiation with UV-containing white light $(315-420 \mathrm{~nm})$ on the anthocyanin content of $D$. carota cell cultures after 7 days of culture, and observed that the total anthocyanin concentration was strongly enhanced by the UV treatment.

The effect of UV irradiation on stilbene content in grapevine cell cultures is little known and most of the research related with UV light has been directed at enhancing the stilbene content of grape berries (Adrian et al., 2000; Versari et al., 2001; Cantos et al., 2003), leaves (Langcake \& Pryce 1977; Pezet et al., 2003) and callus tissue (Keller et al., 2000; Keskin \& Kunter 2008, 2010). In addition, when Keller et al., (2000) studied stilbene accumulation in callus of grapevine irradiated with UV light, they found that only actively growing callus was capable of producing stilbenes (including trans-resveratrol), whereas old callus had lost this ability. This response was similar to that found in ripening grape berries, which gradually lose their potential for synthesizing stilbenes as they approach maturity.

On the other hand, special attention has been paid to the use of chemical compounds such as $\beta$-cyclodextrins (CDs, Fig. 3) which are cyclic oligosaccharides consisting of seven $\alpha-D-$ glucopiranose residues linked by a $(1 \rightarrow 4)$ glucosidic bonds formed by the enzymatic modification of starch. These compounds chemically resemble the alkyl-derived pectic oligosaccharides naturally released from the cell walls during fungal attack (Bru et al., 2006), thus they have been used to increase both the biosynthesis of trans-resveratrol and its secretion to the extracellular medium in $V$. vinifera cell cultures (Morales et al., 1998; Bru \& Pedreño, 2003; Bru et al., 2006). Recently, Zamboni et al., (2009) reported that CDs trigger a signal transduction cascade which activates different families of transcription factors in grapevine cells, inducing a halt in cell division, reinforcement of the cell wall and the biosynthesis of trans-resveratrol and defence-related proteins. The method based on the use of CDs (Bru \& Pedreño, 2003) differs from those that use other elicitors (Liswidowati et al., 1991) not only in the high levels of trans-resveratrol produced but also in the extraction process of this compound. Thus, in traditional elicitation methods, trans-resveratrol is extracted from elicited cells gives low yields, whereas in this new process, trans-resveratrol is secreted as it is produced by cells and recovered directly from the spent media with no biomass destruction. In addition, the high levels of trans-resveratrol accumulated in the culture medium were seen to have no toxic effect on the cell lines, allowing successful subcultures. This innovative elicitation process is mainly based on the CD characteristics. 
They have a hydrophilic external surface and hydrophobic central cavity that can trap hydrophobic compounds, including trans-resveratrol. This hydrophobic cavity forms inclusion complexes, which in the case of CDs with trans-resveratrol, is of the 1:1 type, altering its physicochemical behaviour and making it a highly water-soluble compound (Morales et al., 1998).

This procedure has successful been applied to the production of phytosterols. Thus, SabaterJara et al., (2008) have developed a method based on the use of CDs to enhance phytosterol production by using $D$. carota cell cultures since these cyclic oligosaccharides are able to induce a cascade of cellular events that gives rise to the accumulation of phytosterols.

Methyl jasmonate (MJ, Fig. 3) is considered a key molecule in the signal transduction pathway involved in the induction of the biosynthesis of secondary metabolites which take part in plant defence reactions (Gundlach et al., 1992; Creelman \& Mullet, 1997; Staswick et al., 1998; Chung et al., 2003). In this way, the application of MJ alone or in combination with CDs triggers the accumulation of secondary metabolites in Solanaceae cell cultures, e.g. capsidiol and solavetivone in Capsicum annuum (Ma, 2008; Sabater-Jara et al., 2010b). LeeParsons et al., (2004) showed that C. roseus cell cultures respond to MJ by increasing extracellular accumulation of ajmalicine whose production was dependent on MJ dose and elicitation time. Almagro et al., (2010) demonstrated that the maximum level of ajmalicine produced by cells and secreted to the media was reached when cell suspensions were incubated in the presence of MJ and CDs, production being around 2.2-fold higher than when cells were treated only with CDs.

Moreover, Tassoni et al., (2005) showed that MJ was highly effective in stimulating endogenous trans-resveratrol accumulation, as well as promoting its release into the extracellular medium of $V$. vinifera $c v$ Barbera cell cultures. In this case, the endogenous trans-resveratrol accumulation was around $24 \mu \mathrm{g} / \mathrm{g}$ dry weight (DW) and the transresveratrol secreted to the medium was over $8 \mu \mathrm{g} / \mathrm{g}$ DW. In a similar way, Belhadj et al., (2008) described the production of $0.6 \mathrm{mg}$ trans-resveratrol/g DW in $V$. vinifera cv Gamay elicited with $\mathrm{MJ}$ in a culture medium with the sugar concentration increased. However, the most significant success in increasing trans-resveratrol content in grapevine cell cultures has been reached using CDs alone or in combination with MJ (Pedreño et al., 2009). Lijavetzki et al., (2008) analysed the effects of MJ, CDs and a combination of both on extracellular transresveratrol production and the expression of stilbene biosynthetic genes in grapevine cell cultures. MJ and CDs significantly but transiently induced the expression of stilbene
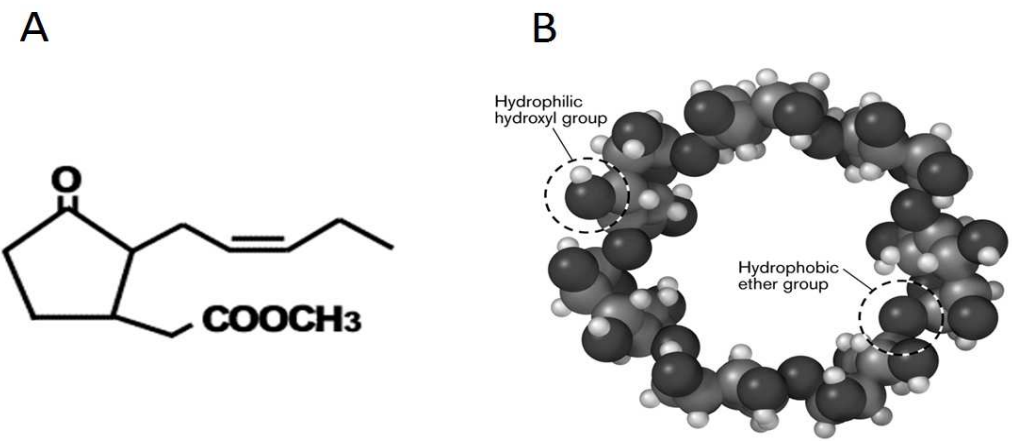

Fig. 3. Structures of methyl jasmonate (A) and cyclodextrins (B). 
biosynthetic genes when used independently to treat grapevine cells. Such expression correlated with trans-resveratrol production in CD-treated cells but not in MJ-treated cells. In the combined treatment involving CDs and MJ, trans-resveratrol production which is secreted to the spent medium, reached a maximum value $(360 \mathrm{mg} / \mathrm{g}$ DW) that was correlated with the maximum expression levels of stilbene biosynthetic genes, demonstrating the synergistic effect of the combination of MJ with CDs (Lijaveztky et al., 2008).

Based on these evidences, the main objective of this chapter is to show the effect of UV light on the production of secondary metabolites in C. roseus, $V$. vinifera and D. carota cell cultures elicited with CDs and MJ, alone or in combination.

\section{Effect of UV light exposure, CDs and MJ on the production of trans- resveratrol}

The production of trans-resveratrol in cell cultures of Vitis $s p$ has been analyzed by several groups (Kiselev 2011 and see therein). Analysis of trans-resveratrol production in untreated Vitis cell cultures (Teguo et al., 1996; Morales et al., 1998; Krisa et al., 1999; Tassoni et al., 2005) revealed a low level of trans-resveratrol accumulation, less than $0.01 \%$ DW or $2-3$ $\mathrm{mg} / \mathrm{l}$. Therefore, various strategies such as the use of biotic and abiotic elicitors, addition of biosynthesis precursors and genetic transformation have been considered to improve the production of trans-resveratrol.

Fig. 4 shows the level of trans-resveratrol $(6.72 \pm 1.03 \mathrm{mg} / \mathrm{g}$ FW) when Monastrell cell cultures were incubated with $50 \mathrm{mM}$ CDs and $100 \mu \mathrm{M}$ MJ, and how this value was higher than when cell cultures were treated only with CDs $(3.15 \pm 0.35 \mathrm{mg} / \mathrm{g} \mathrm{FW})$. However, very low amounts of trans-resveratrol were detected in the spent medium when grapevine cell cultures were elicited only with MJ, and no trans-resveratrol was detected in cell cultures treated with ethanol, the solvent in which MJ is delivered to the culture (data not shown). In a similar way, Krisa et al. (1999) described that the amount of total stilbenes secreted to the culture medium was negligible in both $\mathrm{MJ}$ and control cultures of three $V$. vinifera cultivars. These authors reported that piceid (glucosylated form of resveratrol) accumulation inside the grape cells of Cavernet-Sauvignon cultivar was notably induced when $25 \mu \mathrm{M}$ MJ was added to the induction medium on day $6(6.3 \pm 0.2 \mathrm{mg}$ piceid/g DW). Very low levels of piceid in cells $(9.75 \pm 1.17 \mu \mathrm{g} / \mathrm{g} \mathrm{DW})$ both in the presence of $25 \mu \mathrm{M}$ MJ as when $25 \mu \mathrm{M} \mathrm{MJ}$ and $50 \mathrm{mM}$ CDs were jointly used as inducers $(82.7 \pm 10.9 \mu \mathrm{g} / \mathrm{g} \mathrm{DW}$, Lijavetzki et al., 2008). However, under the last conditions described above, the accumulation of trans-resveratrol in the extracellular medium was $212.6 \pm 12.6 \mathrm{mg} / \mathrm{g}$ DW that is, $10.6 \pm 0.6 \mathrm{mg} / \mathrm{g}$ FW (Pedreño et al., 2009).

On the other hand, Kiselev et al. (2007) reported a high trans-resveratrol production in $V$. amurensis callus cultures transformed with the rolB gene of Agrobacterium rhizogenes ( $31.5 \mathrm{mg}$ trans-resveratrol/g DW) which was 6.7 times lower than those obtained in the culture medium under conditions described above using CDs and MJ jointly.

UV-C light has been described as a physical inductor of stilbene biosynthesis in Vitis sp. As mentioned above, there are no reports on trans-resveratrol production in grapevine cell cultures elicited with UV-C light and most of the research related with UV-C light has been directed at enhancing the stilbene content of grape berries (Adrian et al., 2000; Versari et al., 2001; Cantos et al., 2003; González-Barrio et al., 2006), leaves (Douillet-Breuil et al., 1999; Pezet et al., 2003) and callus tissue (Keller et al., 2000; Keskin \& Kunter 2008). Keller et al., 
(2000) found that only actively growing calli of grapevine cv Cabernet-Sauvignon irradiated with UV-C light were capable of producing stilbenes, whereas old calli had lost this ability. Similar results were described by Keskin \& Kunter (2008) working with CabernetSauvignon callus cultures irradiated with UV-C light. They found that the effect of UV-C light on trans-resveratrol production was dependent on callus age since the highest transresveratrol production was found in 12 day old calli $(62.66 \pm 0.40 \mu \mathrm{g}$ trans-resveratrol/g FW) in comparison with those values obtained in 15 day old calli $(18.12 \pm 0.10 \mu \mathrm{g}$ transresveratrol/g FW) at the same irradiation time $(15 \mathrm{~min})$. In our experiments, Monastrell cell cultures treated with and without MJ and exposed to different UV-C light exposure times produced a negligible extracellular amount of trans-resveratrol and browning cell cultures (data not shown). The results obtained by Keskin \& Kunter (2008) could explain the low

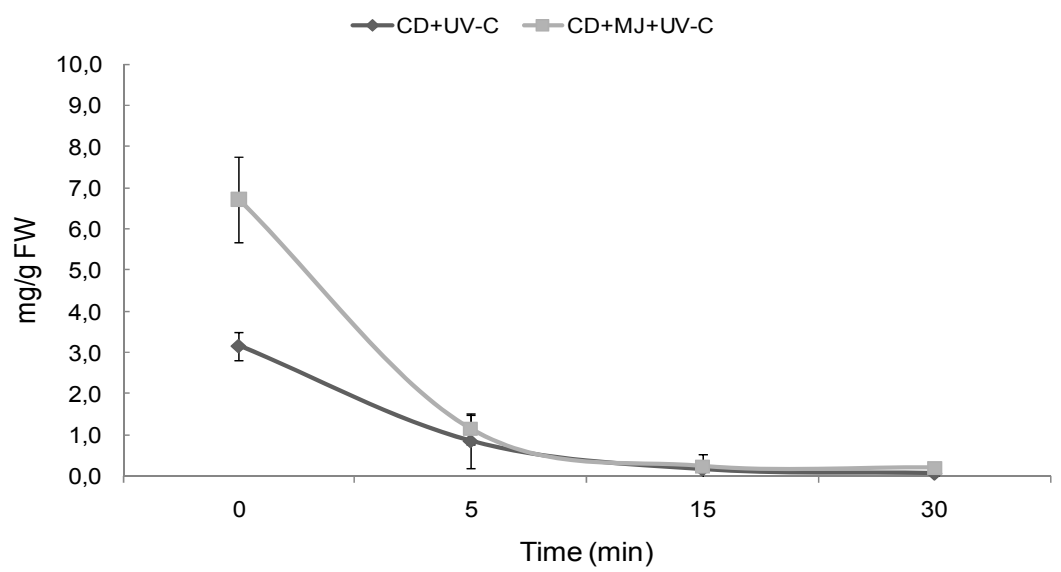

Fig. 4. Effect of UV-C light exposure on the production of trans-resveratrol in Monastrell cell cultures elicited in presence of CDs individually or in combination with MJ. Elicitation experiments were performed in triplicate using 14 day old $V$. vinifera cv Monastrell cell cultures. At zero time, $4 \mathrm{~g}$ of fresh weight (FW) of washed cells were transferred into $100 \mathrm{ml}$ flasks and suspended in $20 \mathrm{ml}$ of Gamborg B 5 medium supplemented as described Bru et al., (2006), and in the presence of CDs alone or in combination with MJ. After that, cell cultures were maintained in a rotary shaker during $96 \mathrm{~h}$ at $25^{\circ} \mathrm{C}$ in darkness. Control treatments without elicitors were always run in parallel (data not shown). In the other cases, elicitation was carried out under UV light at different exposure times in the presence of CDs alone or in combination with MJ. For this, flasks were opened in a laminar flow hood and exposed to UV-C light $\left(254 \mathrm{~nm}, 10 \mu \mathrm{W} / \mathrm{cm}^{2}\right)$ at an irradiation distance of $15 \mathrm{~cm}$. During this time and after irradiation, flasks were kept in continuous agitation for $96 \mathrm{~h}$. After elicitation, cells were separated from the culture medium under a gentle vacuum and the spent medium of $V$. vinifera cell cultures was used for quantifying the trans-resveratrol. For this, aliquots of the spent medium of $V$. vinifera were diluted with water and methanol to a final concentration of $80 \%$ methanol (v/v). $20 \mu \mathrm{l}$ of diluted and filtered samples were analysed in a HPLC-DAD as described Bru et al., (2006). trans-Resveratrol was identified (at $304 \mathrm{~nm}$ ) and quantified by comparison with commercial trans-resveratrol of $>99 \%$ purity. Values are given as the mean $\pm \mathrm{SD}$ of three replicates. 
trans-resveratrol levels found when Monastrell cell cultures were exposed to UV-C light (15 $\mathrm{min})$ and elicited with CDs separately $(0.16 \pm 0.21 \mathrm{mg}$ trans-resveratrol/g FW), and in combination with MJ $(0.24 \pm 0.29 \mathrm{mg}$ trans-resveratrol/g FW), because these elicitation experiments were performed using 12-14 day old grapevine cell cultures which are just entering in their stationary phase.

Moreover, as shown in Fig. 4, Monastrell cell cultures treated with CDs and MJ, followed by short or long exposures to UV-C light, showed lower trans-resveratrol levels ( $5 \mathrm{~min}, 1.14 \pm$ 0.36 and $30 \mathrm{~min}, 0.20 \pm 0.29 \mathrm{mg}$ trans-resveratrol/g FW) than UV-unexposed cells (6.72 \pm $1.03 \mathrm{mg}$ trans-resveratrol/g FW), so that UV-C light exposure was clearly detrimental to trans-resveratrol production. In fact, prolonged exposure to UV-C light (between 15 and 30 min, Fig.4) or even $120 \mathrm{~min}$ (data not shown) caused a drastic reduction in trans-resveratrol accumulation although no cell browning was observed.

However, when Monastrell cell cultures were jointly elicited with CDs and MJ and exposed to UV-A light (Fig. 5), the maximal level of trans-resveratrol was found at long exposures (30 min, $8.26 \pm 0.48 \mathrm{mg} / \mathrm{g} \mathrm{FW}, 90 \mathrm{~min}, 7.20 \pm 1.14 \mathrm{mg} / \mathrm{g} \mathrm{FW}$ ) although no significant differences were found between $\mathrm{CD}+\mathrm{MJ}$-treated cells exposed to UV-A light at these long times and unexposed cells treated with the same chemicals elicitors $(6.72 \pm 1.03 \mathrm{mg} / \mathrm{g} \mathrm{FW})$. By the contrary, at short UV-A light exposures, a drop in the production of trans-resveratrol was observed and this decrease was more drastic when cells were elicited with CDs and MJ jointly (15 min, $3.18 \pm 0.62 \mathrm{mg} / \mathrm{g} \mathrm{FW})$ than in CD-treated cells $(2.20 \pm 0.15 \mathrm{mg} / \mathrm{g} \mathrm{FW})$ in comparison with unexposed-cells (Fig. 5). In addition, when grapevine cell cultures were elicited with CDs and exposed to UV-A during $30 \mathrm{~min}$, a slight increase in the production of trans-resveratrol $(4.50 \pm 0.30 \mathrm{mg} / \mathrm{g} \mathrm{FW})$ was detected in comparison with unexposed CDtreated cells $(3.15 \pm 0.35 \mathrm{mg} / \mathrm{g} \mathrm{FW})$.

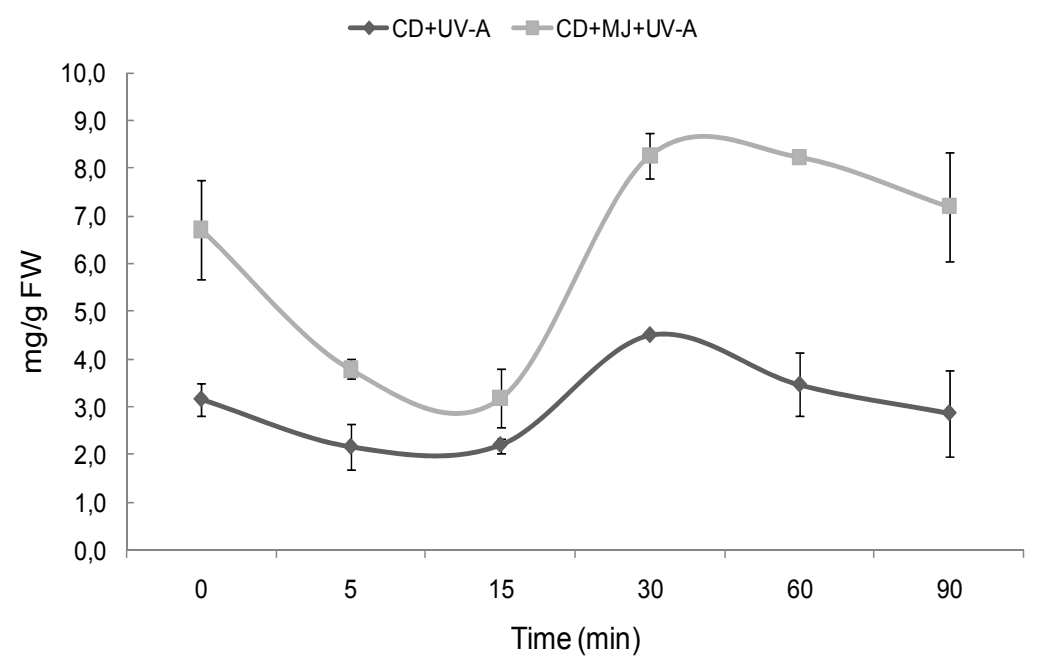

Fig. 5. Effect of the exposure of Monastrell cell cultures to UV-A light (360 nm, 10 $\left.\mathrm{WW} / \mathrm{cm}^{2}\right)$ in presence of CDs individually or in combination with MJ in cells elicited for $96 \mathrm{~h}$. Elicitation experiments and analysis of trans-resveratrol in the culture medium were performed as described in the legend of the Fig.4. Values are given as the mean \pm SD of three replicates. Solid lines represent mg trans-resveratrol/g FW. 
All these results suggested that long UV-A light exposures (30-60 min) only increased slightly the levels of trans-resveratrol when cell cultures were elicited with CDs, and did not enhance trans-resveratrol levels when MJ was also present, so it seems that there is an antagonistic effect between MJ and UV-A light since short UV-A light irradiation decreased drastically the production of trans-resveratrol when cells were elicited in the presence of MJ. In addition, when grapevine cell cultures elicited with or without $\mathrm{MJ}$ in the absence of CDs, and exposed to UV-A light for 15 and $30 \mathrm{~min}$, neither trans-resveratrol nor cell browning was detected (data not shown).

The results suggested that the effect of UV light on trans-resveratrol production was dependent not only on exposition time (short or long) and UV light type (C or A) but also on the presence of one or two chemical elicitors (CDs and/or MJ).

\section{Effect of UV light exposure, CDs and MJ on the production of indole alkaloids}

Fig. 6. shows the effect of the exposure of $C$. roseus cell cultures to UV-C light in the presence of $50 \mathrm{mM}$ CDs and $100 \mu \mathrm{M} \mathrm{MJ}$, separately or in combination. As can be observed, the extracellular accumulation of ajmalicine is dependent on UV-C light time exposure since both short and long UV-C light exposures increased ajmalicine levels in all treatments. However, the maximal levels of ajmalicine were reached when $C$. roseus cell cultures were exposed at UV-C light during $30 \mathrm{~min}$ and these levels of production decreased as UV-C exposures increased. In fact, long UV-C light irradiation (60-90 min, Fig. 6) or even more (120 min, Almagro et al., 2010) caused a reduction in ajmalicine production in comparison with 30 min UV-C treatment (Fig. 6). However, 15 min UV-C irradiation was equivalent to long exposures $(60-90 \mathrm{~min})$ since no significant differences in ajmalicine production were found. In addition, short and long UV-C exposures had no stimulatory effect when C. roseus cell cultures were elicited only with MJ (data not shown). Similarly, control cells treated with short and long UV-C light showed similar low levels of ajmalicine to those unexposed control cells (data not shown). All these results suggested, besides the additive effect observed on ajmalicine accumulation provoked by the joint presence of CDs and MJ, that there was a synergism between these elicitors and UV-C light, and an antagonism between MJ and UV light (short and long exposures) when these elicitors are used to stimulate cells in the absence of CDs (data not shown). This fact may be due to the induction of some sort of stress that does not involve an increase in the production of ajmalicine, while UV-C light exposure may enhance the ajmalicine production but the elicitation in the presence of CDs is needed to provoke any enhancement. Zhao et al., (2001) also observed a synergistic effect on indole alkaloid accumulation in C. roseus cell cultures elicited with fungal preparations and chemicals. Among them, the combination of tetramethyl ammonium bromide and Aspergillum niger mycelial homogenate gave a maximal ajmalicine production of $0.84 \pm$ $0.05 \mathrm{mg} / \mathrm{g} \mathrm{DW}$ and an improved catharanthine accumulation of $0.57 \pm 0.04 \mathrm{mg} / \mathrm{g} \mathrm{DW}$, values that are below those obtained in the best production conditions described above.

Peebles et al., (2009) demonstrated that the octadecanoid pathway, which is involved in the biosynthesis of jasmonates does not actively control the production of indole alkaloids under normal or UV-B stress conditions in C. roseus hairy roots. Their results also suggested that the role of the octadecanoid pathway in the abiotic or biotic stress response may differ, depending on the stress or culture type. In C. roseus cell cultures, the octadecanoid pathway was active when cells were exposed to biotic compounds (e.g. partially purified yeast 
extracts, Menke et al., 1999). If we consider that CDs act in a similar way to fungal elicitors because of they chemically resemble to the alkyl-derived pectic oligosaccharides naturally released from the cell walls during fungal attack (Bru et al. 2006), results described by Peebles et al., (2009) could be agreed with the antagonistic effect observed in our experiments when only MJ and UV light (short and long exposures) were used to elicit $C$. roseus cell cultures.

As regards the production of catharanthine, its level increased when cells were treated with CDs separately or in combination with MJ and exposed to UV-C light both short and long exposure times (Fig. 6). However, the maximal level of catharanthine was observed when cells were exposed 30 min to UV-C irradiation and elicited both with CDs and CDs plus MJ, and no significant differences were found in the rest of experiments under UV light exposure (Fig. 6). There are not reports about how the exposition to UV-C affect to indole alkaloid production and only the effect of UV-B has been tested. In fact, Ramani \& Jayabaskaran (2008) observed the enhanced production of catharanthine and vindoline from C. roseus cell cultures, in where increased their levels 3 and 12 fold, respectively when cells were irradiated with UV-B for $5 \mathrm{~min}$. Although we do not test the effect of UV-B, these results are in accordance with our results since different UV-C exposition times increased the production of catharanthine.

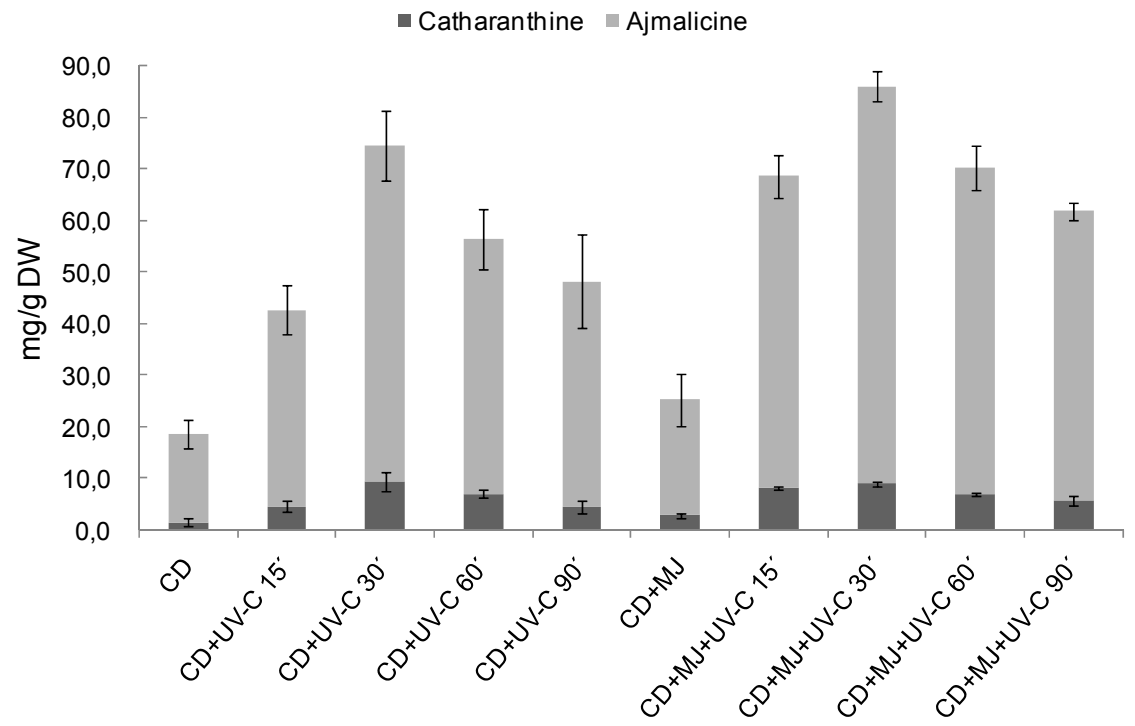

Fig. 6. Effect of different UV-C light exposure times on extracellular accumulation of ajmalicine and catharanthine in cell cultures of $C$. roseus elicited with CDs alone or in combination with MJ.

C. roseus cv First Kiss Apricot cell cultures were obtained as described Almagro et al., (2010). Elicitation experiments were performed in triplicate using 10 day old C. roseus cell cultures. At zero time, cell cultures were elicited in the presence of CDs alone or in combination with $\mathrm{MJ}$ and they were maintained at $25^{\circ} \mathrm{C}$ in a rotary shaker at $110 \mathrm{rpm}$ in darkness. UV light treatments were carried out as described in the legend of Fig. 4. Results were evaluated $96 \mathrm{~h}$ after treatments. Ajmalicine and catharanthine were extracted and analysed as described Almagro et al., (2010). Values are given as the mean \pm SD of three replicates. 
In relation to the effect of UV-A, cell cultures treated with or without MJ and exposed to UV-A light were not able to produce indole alkaloids nor accumulate them in the culture medium (data not shown). However, when C. roseus cell cultures were elicited in the presence of CDs and exposed to UV-A light for 15 and $30 \mathrm{~min}$, the production of ajmalicine increased in relation to non-exposed cells (data not shown) and this increase was similar to that observed in cell cultures elicited, in the same conditions, and irradiated with UV-C light (Fig. 6).

The combination of these three elicitors synergistically increased more the level of indole alkaloids than when each single or two elicitors are used. The reasons why this combination of three elicitors promoted best effects on indole alkaloid production are still not known. Because each chemical elicitor (CDs and/or MJ) or UV light stimulates indole alkaloid accumulation by different pathways, the mechanism for every treatment may be result of combining them since it depends on the interactions between physiological effects caused by the three elicitors.

\section{Effect of UV light exposure, CDs and MJ on the production of phytosterols}

Fig. 7 shows the effect of different UV-C light exposure times on phytosterol production in D. carota cell cultures elicited in the presence of CDs alone or in combination with MJ. As can be observed in this figure, the production of these four phytosterols was greater when cell cultures were elicited in the presence of CDs alone than in those combined with MJ. In addition, control cells elicited with or without MJ and exposed to UV-C light for different exposure times $(15,30$ and $60 \mathrm{~min}$ ) did not produce any of these phytosterols (data not shown). When cell cultures were elicited only with CDs and exposed to UV-C irradiation, total production levels of phytosterols were kept identical to that of unexposed cells and these levels only decrease when the UV light exposure is prolonged (60 min). However, when the cells were elicited with CDs and MJ, a slight enhancement in the total content of phytosterols was observed as the UV-C light exposure times increased (Fig. 7). These results suggested that the production of phytosterols is sustained during UV exposure time through the joint presence of the three elicitors. In these conditions, production levels of fucosterol were lower than those of $\beta$-sitosterol and these, in turn, lower than those of stigmasterol. This low level of fucosterol can be explained by knowing its biosynthetic pathway. All of them are biosynthesized via the mevalonate-dependent isoprenoid pathway. After the synthesis of squalene catalyzed by squalene synthase and its epoxidation catalyzed by squalene epoxidase, 2,3-oxidosqualene is mainly cyclized to cycloartenol which requires cycloartenol synthase (Boutté \& Grebe, 2009). Following conversion of 2,3oxidosqualene to cycloartenol, the first cycle structure providing the basic sterol skeleton, the pathway is essentially linear until reaching 24-methylene lophenol. After formation of this compound, there is a bifurcation to either 24-methyl sterols, which include campesterol and its derivatives, the brassinosteroids, or 24-ethyl sterols, which include the structural sterols fucosterol, $\beta$-sitosterol and stigmasterol (Clouse, 2002; Posé et al., 2009).

The effect of different UV-A light exposure times on phytosterol production in D. carota cell cultures elicited in the presence of CDs alone or in combination with MJ is shown in Fig. 8. Similarly to results described above, when $D$. carota cell cultures were elicited with CDs and exposed to different UV-A irradiation times, total phytosterol content remained 
identical to that of unexposed cells and its level decreased only when the exposition to UV-A was prolonged (Fig. 8). However, the addition of the third elicitor (UV-A) to cells elicited with CDs plus MJ provoked a biphasic response in the production of phytosterols reaching a maximal level when cell cultures were exposed $30 \mathrm{~min}$ to UV-A light. Also, the levels of fucosterol were lower than their derivatives, $\beta$-sitosterol and stigmasterol. It is also worth noting that the production of $\beta$-sitosterol was identical to that of campesterol (Fig. 8).

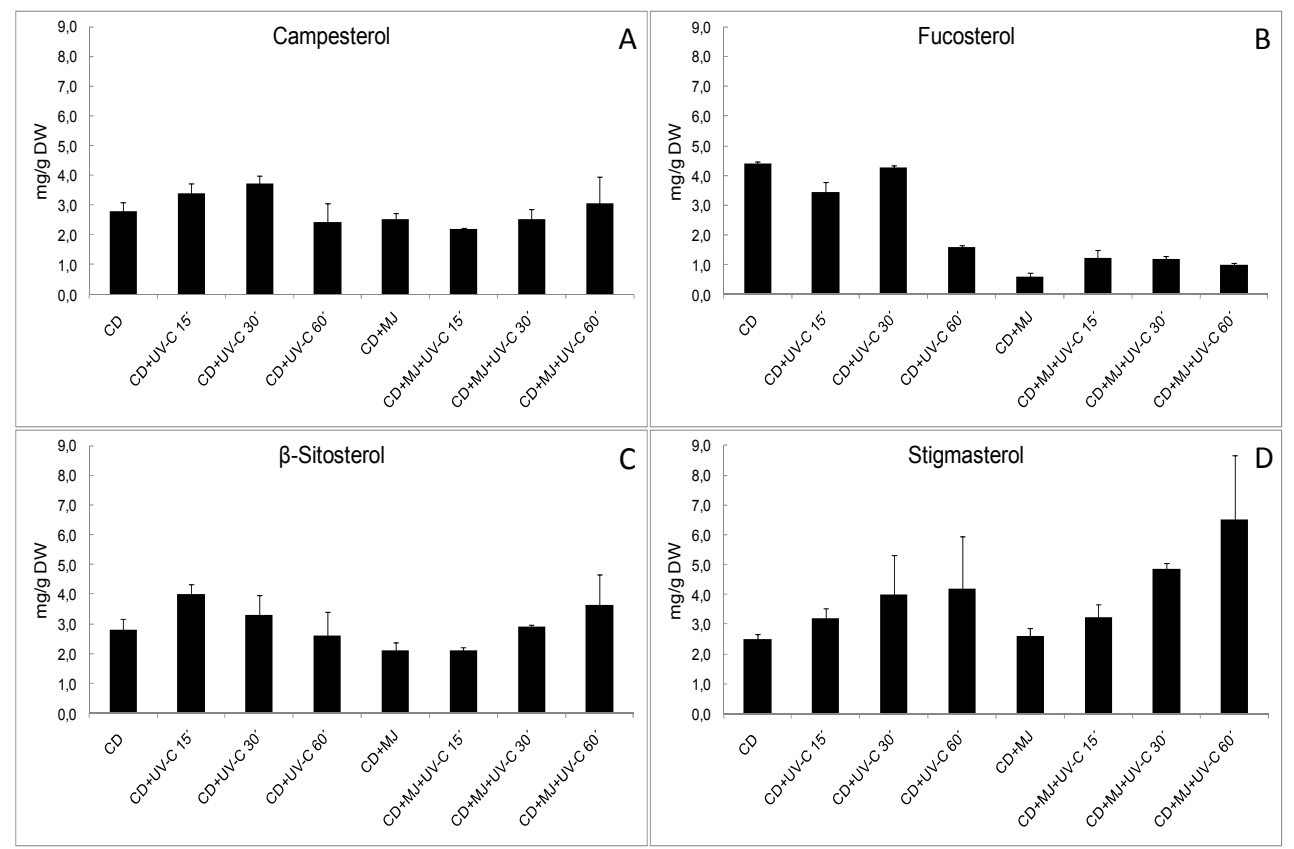

Fig. 7. Effect of different UV-C light exposure times on extracellular accumulation of phytosterols in cell cultures of $D$. carota elicited with CDs alone or in combination with MJ. D. carota calli were established in our laboratory in 2005 from root explants and they have been maintained at light at $25^{\circ} \mathrm{C}$ in $250 \mathrm{ml}$ flasks containing $100 \mathrm{ml}$ of Murashige \& Skoog medium supplemented as described Sabater-Jara et al., (2008). D. carota cell cultures were initiated by inoculating friable callus pieces into $250 \mathrm{ml}$ flasks containing $100 \mathrm{ml}$ of the same medium without agar and were maintained at $25^{\circ} \mathrm{C}$ under a 16 -h light/8-h dark photoperiod at $25^{\circ} \mathrm{C}$ in a rotary shaker at $110 \mathrm{rpm}$. Elicitation experiments were performed in triplicate using 10 day old D. carota as described in the legend to the Fig. 4 . Results were evaluated $96 \mathrm{~h}$ after treatments. Extraction, analysis and identification of different phytosterols in the culture medium were carried out as described Sabater-Jara et al., (2010b). Values are given as the mean $\pm \mathrm{SD}$ of three replicates. Bars represent $\mathrm{mg}$ of different phytosterols/g DW.

As regards the biosynthesis of major components of the phytoalexin complex described in Daucus, the isocoumarin, 6-methoxymellein was detected in those cell cultures jointly elicited with CDs plus MJ both UV-A irradiated and non-irradiated, and its level decreased as UV-A 
exposure time increased (data not shown). Similarly, the accumulation of UV-absorbing compounds, mainly those of phenolic nature, that is, phenylpropanoid derivatives, were observed. In fact, eugenol and isoeugenol were identified both CD- and CD plus MJ-treated cells. The content of these phenols decreased when CD-treated cells were exposed to UV-A light. By the contrary, the levels of these compounds increased in cell cultures elicited with CDs plus MJ and exposed to a short UV-A irradiation (15 $\mathrm{min})$, and they returned to decrease when UV-A exposure time is prolonged (60 min) (data not shown).

Gläßgen et al., (1998) reported that the biosynthesis and accumulation of anthocyanins in carrot cell cultures was strongly enhanced by continuous irradiation with UV-containing white light $(315-420 \mathrm{~nm})$ and that was preceded by the corresponding induction of the enzymes activities of the phenylpropanoid and flavonoid pathways. These authors also showed that the treatment with UV-A light and fungal elicitors resulted in a rapid induction of the phenylpropanoid pathway, whereas the inducing effect of UV-A light on the anthocyanin content, on chalcone synthase and on the enzymes catalyzing the final steps of anthocyanins biosynthesis was suppressed. Their results indicated a coordinated regulation of the enzymes involved in anthocyanins biosynthesis, an independent inducibility of the phenylpropanoid pathway, and a hierarchy of the different effectors, as shown by the dominating role of the fungal elicitor signal over the UV stimulus.

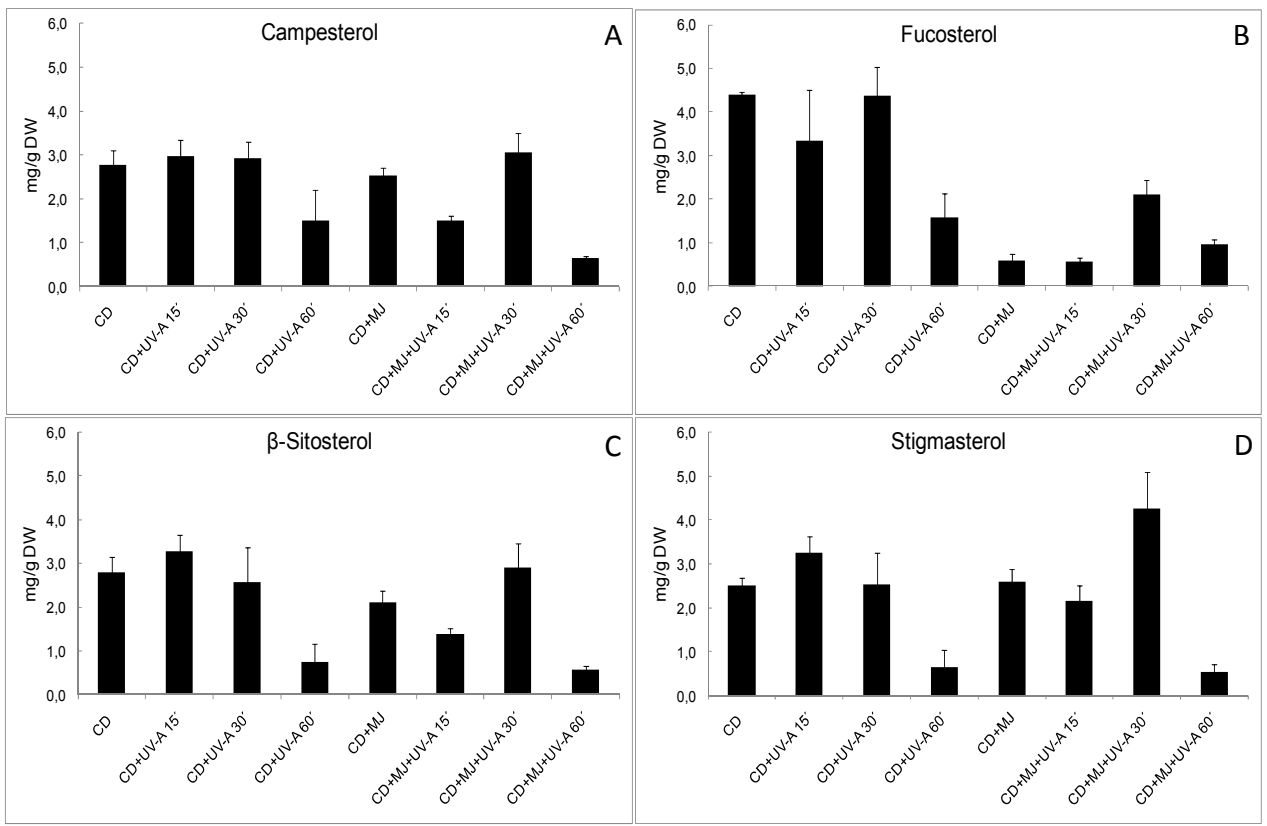

Fig. 8. Effect of different UV-A light $\left(360 \mathrm{~nm}, 10 \mu \mathrm{W} / \mathrm{cm}^{2}\right)$ exposure times on extracellular accumulation of phytosterols in cell cultures of $D$. carota elicited with CDs alone or in combination with MJ. Elicitation experiments, extraction, analysis and identification of different phytosterols in the culture medium were performed as described in the legend of the Fig. 7. Values are given as the mean $\pm \mathrm{SD}$ of three replicates. Bars represent $\mathrm{mg}$ of different phytosterols/g DW. 
Therefore, it is possible to think that, in the simultaneous treatment of carrot cells with UVA light and elicitors, the chemical elicitor signal was dominant over the UV light signal, resulting in the UV induction or inhibition of different biosynthetic pathways which leads to phenylpropanoid or flavonoid derivatives.

\section{Conclusion}

The application of biotic or abiotic stimuli has been one of the most effective strategies for improving the productivity of different useful secondary metabolites from plant cell cultures (Vasconsuelo \& Boland, 2007; Zhao et al., 2005). The most frequently used elicitors are of fungal and yeast origin, jasmonic acid and MJ, chitosan, metal ions and UV light.

More recently, special attention has been paid to the use of CDs as true elicitors, which act inducing defence responses, which include pathogenesis-related proteins and phytoalexin synthesis, especially the stilbenes like trans-resveratrol in Vitis sp (Morales et al., 1998; Bru et al., 2006; Zamboni et al., 2009; Martinez-Esteso et al. 2009), the accumulation of sesquiterpenes and phytosterols as well as pathogenesis-related proteins in Capsicum sp (Sabater-Jara et al., 2010b; Sabater-Jara et al., 2011), the increase of ajmalicine and catharanthine in C. roseus (Almagro et al., 2010) and the enhancement of the production of silymarin in Silybum marianum (L.) Gaernt cell cultures (Belchí-Navarro et al., 2011). The success in the production of secondary metabolites with the use of CDs lies in the properties of these compounds since they act not only as elicitors but also forming inclusion complexes (clathrates) with stilbenes (Morales et al., 1998), sesquiterpenes (Sabater-Jara et al., 2010b), indole alkaloids (Almagro et al, 2010) and silymarins (Belchí-Navarro et al., 2011), favouring the substantial accumulation of these metabolites and also preventing the toxic and/or inhibitory effect of their extracellular accumulation on cells cultured in suspension.

Most of the publications concerning secondary metabolite production by means of plant cell cultures reported that the elicitation with MJ increased the accumulation of secondary metabolites (Zhao et al., 2005; Sánchez-Sampedro et al., 2005; Belchí-Navarro et al., 2011; Almagro et al., 2010; Lee-Parsons et al., 2004; Repka et al., 2004; Szabo et al., 1999; Tassoni et al., 2005; Yukimune et al., 1996; Mandujano-Chavez et al., 2000; Sabater-Jara et al., 2010a,b; Wang \& Wu, 2005). In fact, the addition of a second elicitor, for instance MJ to cell cultures elicited with CDs increased significantly the production of trans-resveratrol, indole alkaloids and phytosterols in Monastrell grapevine, C. roseus and D. carota cell cultures, respectively. However, the effect of UV light on the production of these secondary metabolites is dependent not only on the exposition time (short or long) and UV light type (C or A), but also on the presence of one (CDs) or two chemical elicitors (CDs and MJ). Thus, the addition of a third elicitor (UV light) in Monastrell grapevine cell cultures, elicited with CDs separately or in combination with MJ, decreased (UV-C light, Fig. 4) or did not increase significantly the production of trans-resveratrol (UV-A light, Fig. 5). By the contrary, to achieve high ajmalicine production levels using a productive $C$. roseus cell line, the best operating conditions were elicitation using a combination of CDs and MJ and a cell exposition to UV light (A or C) during 30 min although this enhancement was also observed at all irradiation times tested (Fig. 6). Moreover, the production of phytosterols depended on exposition time (short or long) and UV light type (C or A) since the exposition of D. carota cell cultures to UV-C light did not increase phytosterol extracellular accumulation in CD- or CD plus MJ-treated cells (Fig. 7) whereas in cells elicited with CDs and MJ and exposed to UV-A during $30 \mathrm{~min}$, an increase in the phytosterol production was observed (Fig. 8). The 
mechanism by which the elicitor signal leads to suppression or activation of metabolite biosynthesis has yet to be investigated. All effects observed after application of the elicitors alone or in combination with UV light may be regulated at the level of both protein and mRNA of crucial enzymes whose activities increased or decreased. Further experiments are needed in order to elucidate the mechanism by which the joint action of three different elicitors in some cases, improves the production of secondary metabolites while in others, no effect is observed.

\section{Acknowledgments}

Almagro L., Sabater-Jara AB., Fernández-Pérez F. held grants from the Ministerio de Ciencia e Innovación. We thank Pepita Alemán for help in maintaining Monastrell cell cultures. This work has been supported by Fundación Séneca (08799/PI/08) and Ministerio de Ciencia e Innovación (BIO2005-00332 and BIO2008-02941).

\section{References}

Adrian, M.; Jeandet, P.; Douillet-Breuil, AC.; Tesson, L. \& Bessis, R. (2000). Stilbene content of mature Vitis vinifera berries in response to UV-C elicitation. Journal of Agricultural and Food Chemistry, Vol.48, No.12, (November 2000), pp. 6103-6105, ISSN 0021-8561

Almagro, L.; López-Pérez, AJ. \& Pedreño, MA. (2010). New method to enhance ajmalicine production in Catharanthus roseus cell cultures based on the use of cyclodextrins. Biotechnology Letters, Vol.33, No.2, (October 2010), pp. 381-385, ISSN 0141-5492

Asada, M. \& Shuler, ML. (1989). Stimulation of ajmalicine production and excretion from Catharanthus roseus: effects of adsorption in situ, elicitors, and alginate immobilization. Applied Microbiology and Biotechnology, Vol.30, No.5, (May 1989), pp. 475-481, ISSN 0175-7598

Baur, JA.; Pearson, KJ.; Price, NL.; Jamieson, HA.; Lerin, C.; Kalra, A.; Prabhu, VV.; Allard, JS.; Lopez-Lluch, G. \& Lewis, K. (2006). Resveratrol improves health and survival of mice on a high-calorie diet. Nature, Vol.444, (November 2006), pp. 337-342, ISSN 0028-0836

Belchí-Navarro, S.; Pedreño, MA. \& Corchete, P. (2011). Methyl jasmonate increases silymarin production in Silybum marianum (L.) Gaernt cell cultures treated with $\beta$ cyclodextrins. Biotechnology Letters, Vol.33, No.11, (January 2011), pp. 179-184, ISSN 0141-5492

Belhadj, A.; Telef, N. \& Saigne, C. (2008). Effect of methyl jasmonate in combination with carbohydrates on gene expression of PR proteins, stilbene and anthocyanin accumulation in grapevine cell cultures. Plant Physiology and Biochemistry, Vol.46, No.4, (April 2008), pp. 493-499, ISSN 0981-9428

Bishayee, A.; Sarkar, A. \& Chatterjee, M. (1995). Hepatoprotective activity of carrot (Daucus carota L.) against carbon tetrachloride intoxication in mouse liver. Journal of Ethnopharmacology, Vol.47, No.2 (July 1995), pp. 69-74, ISSN 0378-8741

Bonfill, M.; Mangas, S.; Moyano, E.; Cusido, RM. \& Palazón, J. (2011). Production of centellosides and phytosterols in cell suspension cultures of Centella asiatica. Plant Cell Tissue and Organ Culture, Vol.104, No.1, (January 2011), pp. 61-67, ISSN 01676857

Bornman, JF.; Reuber, S.; Cen, YP. \& Weissenböck, G. (1997). Ultraviolet radiation as a stress factor and the role of protective pigments. In: Plants and UV-B: Responses to 
Environmental Change, P.J. Lumsden, (Ed.), 157-168, Cambridge University Press, ISBN 978-052-1572-22-4, Cambridge, United Kingdon

Boutté, Y. \& Grebe, M. (2009). Cellular processes relying on sterol function in plants. Current Opinion in Plant Biology, Vol.12, No.6, pp. 705?713, (December 2009), ISSN 13695266

Bradamante, S.; Barenghi, L. \& Villa, A. (2004). Cardiovascular protective effects of resveratrol. Cardiovascular Drug Reviews, Vol.22, No.3, (June 2006), pp. 169 -188, ISSN 0897-5957

Broeckling, CD.; Huhman, DV.; Farag, MA.; Smith, JT.; May, GD.; Mendes, P.; Dixon, RA. \& Sumner, LW. (2005). Metabolic profiling of Medicago trunculata cell cultures reveals the effects of biotic and abiotic elicitors on metabolism. Journal of Experimental Botany, Vol.53, No.410, (December 2004), pp. 323-326, ISSN 0022-0957

Bru, R. \& Pedreño, MA. (2003). Method for the production of resveratrol in cell cultures. PCT patent WO/2003/062406. US 2006/0205049 A1

Bru, R.; Selles, S.; Casado-Vela, J.; Belchí-Navarro, S. \& Pedreño, MA. (2006). Modified cyclodextrins are chemically defined glucan inducers of defense responses in grapevine cell cultures. Journal of Agricultural and Food Chemistry, Vol.54, No.1, (December 2005), pp. 65-71, ISSN 0021-8561

Calderón, AA.; Zapata, JM.; Muñoz, R.; Pedreño, MA. \& Ros-Barcelo, A. (1993). Resveratrol production as a part of the hypersensitive-like response of grapevine cells to an elicitor from Trichoderma viride. New Phytologist, Vol.124, No.3, (July 1993), pp. 455-463, ISSN 0028-646X

Cantos, E.; Espín, JC.; Fernández, MJ.; Oliva, J. \& Tomás-Barberán, FA. (2003). Postharvest UV-C irradiated grapes as potential source for producing stilbene-enriched red wines. Journal of Agricultural and Food Chemistry, Vol.51, No.5, (January 2003), pp. 1208-1214, ISSN 0021-8561

Chung, I.; Park, MR.; Chun, JC. \& Yun, SJ. (2003). Resveratrol accumulation and resveratrol synthase gene expression in response to abiotic stresses and hormones in peanut plants. Plant Science, Vol.164, No.1, (January 2003), pp. 103-109, ISSN 0168-9452

Clouse, S. (2002). Arabidopsis mutants reveal multiple roles for sterols in plant development. Plant Cell, Vol.14, No.9, (September 2002), pp. 1995-2000, ISSN 10402519

Creelman, RA. \& Mullet, JE. (1997). Biosynthesis and action of jasmonates in plants. Annual Review of Plant Physiology and Plant Molecular Biology, Vol.48, (June 1997), pp. 355381, ISSN 1040-2519

De la Lastra, C. \& Villegas, I. (2005). Resveratrol as an anti-inflammatory and anti-aging agent: mechanisms and clinical implications. Molecular Nutrition \& Food Research, Vol.49, No.5, (May 2005), pp. 405-430, ISSN 1613-4125

Delgado-Zamarreño, MM.; Bustamante-Rangel, M.; Martínez-Pelarda, D. \& CarabíasMartínez, R. (2009). Analysis of $\beta$-sitosterol in seeds and nuts using pressurized liquid extraction and liquid chromatography. Analytical Science, Vol.25, No.6, (June 2009), pp. 765-768, ISSN 0910-6340

Douillet-Breuil, AC.; Jeandet, P.; Adrian, M. \& Bessis, R. (1999). Changes in the phytoalexin content of various Vitis spp. in response to ultraviolet $\mathrm{C}$ elicitation. Journal of Agricultural and Food Chemistry, Vol.47, No.10, (September 1999), pp. 4456-4461, ISSN 0021-8561

Espín, JC.; García-Conesa, MT. \& Tomás-Barberán, FA. (2007). Nutraceuticals: Facts and fiction. Phytochemistry, Vol.68, No.22, (September 2007), pp. 2986-3008, ISSN 00319422 
Fu, HW.; Zhang, L.; Yi, T. \& Tian, JK. (2009). A new sesquiterpene from the fruits of Daucus carota L. Molecules, Vol.14, No.8, (August 2009), pp. 2862-2867, ISSN 1420-3049

Gläßgen, WE.; Rose, A.; Madlung, J.; Koch, W.; Gleitz, J. \& Seitz, HU. (1998). Regulation of enzymes involved in anthocyanin biosynthesis in carrot cell cultures in response to treatment with ultraviolet light and fungal elicitors. Planta, Vol.204, No.4, (October 2007), pp. 490-498, ISSN 0032-0935

González-Barrio, R.; Beltrán, D.; Cantos, E.; Gil, MI.; Espín, JC. \& Tomás-Barberán, FA. (2006). Comparison of Ozone and UV-C Treatments on the Postharvest Stilbenoid Monomers, Dimers and Trimers Induction in Var. 'Superior' White Table Grapes. Journal of Agricultural and Food Chemistry, Vol.54, No.12, (May 2006), pp. 4222-4228 ISSN 0021-8561

Gundlach, H.; Müller, MJ.; Kutchan, TM. \& Zenk, MH. (1992). Jasmonic acid is a signal transducer in elicitor-induced plant cell cultures. Procedings of the National Academy of Science of the USA, Vol.89, No.6, (March 1992), pp. 2389-2393, ISSN 0027-8424

He, S.; Wu, B.; Pan, Y. \& Jiang, L. (2008). Stilbene oligomers from Parthenocissus laetevirens: isolation, biomimetic synthesis, absolute configuration, and implication of antioxidative defense system in the plant. Journal of Organic Chemistry, Vol.73, No.14, (June 2008), pp. 5233-5241, ISSN 0022-3263

Herchi, W.; Harrabi, S.; Sebei, K.; Rochut, S.; Boukhchina, S.; Pepe, C. \& Kallel, H. (2009). Phytosterols accumulation in the seeds of Linum usitatissimum L. Plant Physiology and Biochemistry, Vol.47, No.10, (October 2009), pp. 880-885, ISSN 0981-9428

Jeandet, P.; Bessis, R. \& Gautheron, B. (1991). The production of resveratrol (3,5,4'trihydroxystilbene) by grape berries in different developmental stages. American Journal of Enology and Viticulture, Vol.42, No.1, (May 1991), pp. 41-46, ISSN 00029254

Jeandet, P.; Douillet-Breuil, AC.; Bessis, R.; Debord, S.; Sbaghi, M. \& Adrian, M. (2002). Phytoalexins from the Vitaceae: biosynthesis, phytoalexin gene expression in transgenic plants, antifungal activity, and metabolism. Journal of Agricultural and Food Chemistry, Vol.50, No.10, (April 2002), pp. 2731-2741, ISSN 0021-8561

Kaeberlein, M. \& Rabinovitch, PS. (2006). Medicine: grapes versus gluttony. Nature, Vol.16 No.444, (November 2006), pp. 280-281, ISSN 0028-0836

Keller, M.; Steel, CC. \& Creasy, GL. (2000). Stilbene accumulation in grapevine tissues: Developmental and environmental effects. Acta Horticulturae, No.514, (August 2000), pp. 275-286, ISSN 0567-7572

Keskin, N. \& Kunter, B. (2008). Production of trans-resveratrol in Cabernet Sauvignon (Vitis vinifera L.) callus culture in response to ultraviolet-C irradiation. Vitis, Vol.47, No.4, pp. 193-196, ISSN 0042-7500

Keskin, N. \& Kunter, B. (2010). Production of trans-resveratrol in callus tissue of öküzgözü (Vitis vinifera L.) in response to ultraviolet-C irradiation. Journal of Animal $\mathcal{E}$ Plant Sciences, Vol.20, No.3, (September 2010), pp. 197-200, ISSN 1018-7081

Kiselev, KV. (2011). Perspectives for production and application of resveratrol. Applyed Microbiology and Biotechnology, Vol.90, No.2, (March 2011), pp. 417-425, ISSN 01757598

Kiselev, KV.; Dubrovina, AS.; Veselova, MV.; Bulgakov, VP.; Fedoreyev, SA. \& Zhuravlev, YN. (2007). The rolB gene-induced overproduction of resveratrol in Vitis amurensis transformed cells. Journal of Biotechnology, Vol.128, No.3, (November 2006), pp. 681692, ISSN 0168-1656

Krisa, S.; Larronde, F.; Budzinski, H.; Decendit, A.; Deffieux, G. \& Mérillon, JM. (1999). Stilbene production by Vitis vinifera cell suspension cultures: methyl jasmonate 
induction and 13C biolabelling. Journal of Natural Products, Vol.62, No.12, (November 1999), pp. 1688-1690, ISSN 0163-3864

Langcake, P. \& Pryce, RJ. (1977). The production of resveratrol and the viniferins by grapevines in response to ultraviolet irradiations. Phytochemistry, Vol.16, No.8, (February 1977), pp. 1193-1196, ISSN 0031-9422

Lee, MH.; Jeong, JH.; Seo, JW.; Shin, CG.; Kim, YS.; In, JG.; Yang, DC.; Yi, JS. \& Choi, YE. (2004). Enhanced triterpene and phytosterol biosynthesis in Panax ginseng overexpressing squalene synthase gene. Plant Cell Physiology, Vol.45, No.8, (August 2004), pp. 976-984, ISSN 1471-9053

Lee-Parsons, CWT.; Ertürk, S. \& Tengtrakool, J. (2004). Enhancement of ajmalicine production in Catharanthus roseus cell cultures with methyl jasmonate is dependent on timing and dosage of elicitation. Biotechnology Letters, Vol.26, No.20, (October 2004), pp. 1595-1599, ISSN 0141-5492

Lijavetzky, D.; Almagro, L.; Belchí-Navarro, S.; Martínez-Zapater, JM.; Bru, R. \& Pedreño, MA. (2008). Synergistic effect of methyljasmonate and cyclodextrin on stilbene biosynthesis pathway gene expression and resveratrol production in Monastrell grapevine cell cultures. BMC Research Notes, Vol.1, No.132, (December 2008), pp. 18, ISSN 1756-0500

Liswidowati, FM.; Melchior, F.; Hohmann, F.; Schwer, B. \& Kindl, H. (1991). Induction of stilbene synthase by Botrytis cinerea in cultured grapevine cells. Planta, Vol.183, No.2, (January 1991), pp. 307-314, ISSN 0032-0935

Ma, CJ. (2008). Cellulase elicitor induced accumulation of capsidiol in Capsicum annuum L. suspension cultures. Biotechnology Letters, Vol.30, No.5, (May 2008), pp. 961-965, ISSN 0141-5492

Mandujano-Chavez, A.; Schoenbeck, MA.; Ralston, LF.; Lozoya-Gloria, E. \& Chappell, J. (2000). Differential induction of sesquiterpene metabolism in tobacco cell suspension cultures by methyl jasmonate and fungal elicitor. Archives of Biochemistry and Biophysics, Vol.381, No.2, (September 200), pp. 285-294, ISSN 00039861

Marinelli, F.; Ronchi, VN. \& Salvadori, P. (1994). Elicitor induction of enzyme activities and 6-methoxymellein production in carrot cell suspension culture. Phytochemistry, Vol.35, No.6, (April 1994), pp. 1457-1460, ISSN 0031-9422

Martinez-Esteso, MJ.; Sellés-Marchart, S.; Vera-Urbina, JC.; Pedreño, MA. \& Bru, R. (2009). Changes of defense proteins in the extracellular proteome of grapevine (Vitis vinifera cv. Gamay) cell cultures in response to elicitors. Journal of Proteomics, Vol.73, No.2, (December 2009), pp. 331-341, ISSN 1874-3919

Menke, FL.; Parchmann, S.; Mueller, MJ.; Kijne, JW. \& Memelink, J. (1999). Involvement of the octadecanoid pathway and protein phosphorylation in fungal elicitorinduced expression of terpenoid indole alkaloid biosynthetic genes in Catharanthus roseus. Plant Physiology, Vol.119, No.4 (April 1999), pp.1289-1296, ISSN 0032-0889

Mercier, J.; Roussel, D.; Charles, MT. \& Arul, J. (2000). Systemic and local responses associated with UV-induced and pathogen induced resistance to Botrytis cinerea in stored carrot. Phytopathology, Vol.90, No.9, (September 2000), pp. 981-986, ISSN 0031-949X

Morales, M.; Bru, R.; García-Carmona, F.; Ros Barceló, A. \& Pedreño, MA. (1998). Effect of dimethyl- $\beta$-cyclodextrins on resveratrol metabolism in Gamay grapevine cell cultures before and after inoculation with shape Xylophilus ampelinus. Plant Cell Tissue and Organ Culture, Vol.53, No.3, (June 1998), pp. 179-187, ISSN 0167-6857 
Morel, G. (1970) Le problème de la transformation tumorale chez les végétaux. Physiology Végétale, Vol.8, No.2, (January 1970), pp. 189-191, ISSN 0031-9368

Okawara, M.; Katsuki, H.; Kurimoto, E.; Shibata, H.; Kume, T. \& Akaike, A. (2006). Resveratrol protects dopaminergic neurons in midbrain slice culture from multiple insults. Biochemical Pharmacology, Vol.73, No.4, (February 2007), pp. 550-560, ISSN 0006-2952.

Ouwerkerk, PBF.; Trimborn, TO.; Hilliou, F. \& Memelink, J. (1999). Nuclear factors GT-1 and 3AF1 interact with multiple sequences within the promoter of the Tdc gene from Madagascar periwinkle: GT-1 is involved in UV light-induced expression. Molecular E General Genetics, Vol.261, No.4, (June 1999), pp. 610-622, ISSN 0026-8925

Pant, B. \& Manandhar, S. (2007). In vitro propagation of carrot (Daucus carota). Scientific World, Vol.5, No.5, (July 2007), pp. 51-53, ISSN 1996-8949

Pedreño, MA.; Belchí-Navarro, S.; Almagro, L. \& Bru, R. (2009). Uso combinado de metil jasmonato y ciclodextrinas para la producción de resveratrol. PCT patent WO/2009/106662

Peebles, CAM.; Shanks, JV. \& San, KY. (2009). The Role of the Octadecanoid Pathway in the Production of Terpenoid Indole Alkaloids in Catharanthus roseus Hairy Roots Under Normal and UV-B Stress Conditions. Biotechnology and Bioengineering, Vol.103, No.6, (April 2009), pp.1248-1254, ISSN 0006-3592

Pervaiz, S. (2003). Resveratrol: from grapevines to mammalian biology. Journal of the Federation of American Societies for Experimental Biology, Vol.17, No.14, (November 2003), pp. 1975-1985, ISSN 0892-6638

Pezet, R.; Gindro, K.; Viret, O. \& Richter, H. (2004). Effects of resveratrol and pterostilbene on Plasmopara viticola zoospore mobility and disease development. Vitis, Vol.43, No.3, pp. 145-148, ISSN 0042-7500

Pezet, R.; Perret, C.; Jean-Denis, JB.; Tabacchi, R.; Gindro, K. \& Viret, O. (2003). ठ-Viniferin, a resveratrol dehydrodimer: One of the major stilbenes synthesized by stressed grapevine leaves. Journal of Agricultural and Food Chemistry, Vol.51, No.18, (July 2003), pp. 5488-5492, ISSN 0021-8561

Pezzuto, JM. (2008). Resveratrol as an inhibitor of carcinogenesis. Pharmaceutical Biology, Vol.46, No.7, (July 2008), pp. 443-573, ISSN 1388-0209

Posé, D.; Castanedo, I.; Borsani, O.; Nieto, B.; Rosado, A.; Taconnat, L.; Ferrer, A.; Dolan, L.; Valpuesta, V. \& Botella, MA. (2009). Identification of the Arabidopsis dry2/sqe1-5 mutant reveals a central role for sterols in drought tolerance and regulation of reactive oxygen species. Plant Journal, Vol.59, No.1, (July 2009), pp. 63-76, ISSN 0960-7412

Privat, C.; Telo, JP.; Bernardes-Genisson, V.; Vieira, A.; Souchard, JP. \& Nepveu, F. (2002). Antioxidant properties of trans-epsilon-viniferin as compared to stilbene derivatives in aqueous and nonaqueous media. Journal of Agricultural and Food Chemistry, Vol.50, No.5, (January 2002), pp. 1213-1217, ISSN 0021-8561

Ramani, S. \& Jayabaskaran, C. (2008). Enhanced catharathine and vindoline production in suspension cultures of Catharanthus roseus by ultraviolet-B light. Journal of Molecular Signaling, Vol.3, No.9, (April 2008), pp. 1-6, ISSN 1750-2187

Repka, V.; Fischerová, I. \& Silhárova, K. (2004). Methyl jasmonate is a potent elicitor of multiple defense responses in grapevine leaves and cell-suspension cultures. Biologia Plantarum, Vol.48, No.2, (May 2003), pp. 273-283, ISSN 0006-3134

Rossi, PG.; Bao, L.; Luciani, A.; Panighi, J.; Desjobert, JM.; Costa, J.; Casanova, J.; Bolla, JM. \& Berti, L. (2007). (E)-methylisoeugenol and elemicin: antibacterial components of 
Daucus carota L. essential oil against Campylobacter jejuni. Journal of Agricultural and Food Chemistry, Vol.5, No.18, (August 2007), pp. 7332-7336, ISSN 0021-8561

Sabater-Jara, AB.; Almagro, A.; Belchí-Navarro, S. \& Pedreño, MA. (2010a). A new strategy to enhance the production of phytosterols in Daucus carota cell cultures, XVIII Congress of the Federation of European Societies of Plant Biology 2010, pp. 90, Valencia, Spain, July 4-9, 2010

Sabater-Jara, AB.; Almagro, A.; Belchí-Navarro, S.; Ferrer, MA.; Ros-Barceló, A. \& Pedreño, MA. (2010b). Induction of sesquiterpenes, phytoesterols and extracellular pathogenesis-related proteins in elicited cell cultures of Capsicum annuum. Journal of Plant Physiology, Vol.167, No.15, (October 2010), pp. 1273-1281, ISSN 0176-1617

Sabater-Jara, AB.; Almagro, L.; Belchí-Navarro, S.; Barceló, AR. \& Pedreño, MA. (2011). Methyl jasmonate induces extracellular pathogenesis-related proteins in cell cultures of Capsicum chinense. Plant Signaling and Behaviour, Vol.6, No.3, (March 2011), pp. 440-442, ISSN 1559-2316

Sabater-Jara, AB.; Almagro, L.; Bru, R. \& Pedreño, MA. (2008). Use of cyclodextrins to produce and extract phytoesterols from cell cultures. PCT patent WO/2010/049563

Sánchez-Sampedro, MA.; Fermández-Tárrago, J. \& Corchete, P. (2005). Yeast extract and methyl jasmonate-induced silymarin in cell cultures of Silybum marianum (L.) Gaertn. Journal of Biotechnology, Vol.119, No.1, (September 2005), pp. 60-69, ISSN 0168-1656

Searles, PS.; Kropp, BR.; Flint, SD. \& Caldwell, MM. (2001). Influence of solar UV-B radiation on peatland microbial communities of southern Argentinia. New Phytologist, Vol.152, No.2, (November 2001), pp. 213-221, ISSN 0028-646X

Seigler, DS. (2006). Basic pathways for the origin of allelopathic compounds, In: Allelopathy: A Physiological Process with Ecological Implications, M.J. Reigosa, N. Pedrol and L. González, (Ed.), 11-58, Springer, ISBN 1-4020-4280-9-2, Netherlands.

Shakibaei, M.; Harikumar, KB. \& Aggarwal, BB. (2009). Resveratrol addiction: To die or not to die. Molecular nutrition and food research, Vol.53, No.1, (January 2009), pp. 115-128, ISSN 1613-4125

Sheahan, JJ. (1996). Sinapate Esters Provide Greater UV-B Attenuation than Flavonoids in Arabidopsis thaliana (Brassicaceae). American Journal of Botany, Vol.83, No.6, (June 1996), pp. 679-686, ISSN 0002-9122

Siemann, EH. \& Creasy, LL. (1992). Concentration of the Phytoalexin Resveratrol in Wine. American Journal of Enology and Viticulturae, Vol.43, No.1, (July 1992), pp. 49-525, ISSN 0002-9254

Staswick, PE.; Yuen, GY. \& Lehman, CC. (1998). Jasmonate signaling mutants of Arabidopsis are susceptible to the soil fungus Pythium irregulare. Plant Journal, Vol.15, No.6, (September 1998), pp. 747-754, ISSN 0960-7412

Szabo, E.; Thelen, A. \& Petersen, M. (1999). Fungal elicitor preparations and methyl jasmonate enhance rosmarinic acid accumulation in suspension cultures of Coleus blumei. Plant Cell Report, Vol.18, No.6, (February 1999), pp. 485-489, ISSN 0721-7714

Tassoni, A.; Fornalé, S.; Franceschetti, M.; Musiani, F.; Micheal, AJ.; Perry, B. \& Bagni, N. (2005). Jasmonates and Na-orthovanadate promote resveratrol production in Vitis vinifera L. cv. Barbera cell cultures. New Phytolgist, Vol.166, No.3, (June 2005), pp. 895-905, ISSN 0028-646X

Tavares, AC.; Goncalves, MJ.; Cavaleiro, C.; Cruz, MT.; Lopes, MC.; Canhoto, J. \& Salgueiro, LR. (2008). Essential oil of Daucus carota subsp. halophilus: Composition, antifungal activity and cytotoxicity. Journal of Ethnopharmacology, Vol.119, No.1, (September 2008), pp. 129-134, ISSN 0378-8741 
Teguo, WP.; Fauconneau, B.; Deffieux, G.; Huguet, F.; Vercauteren, J. \& Merillon, JM. (1998). Isolation, identification, and antioxidant activity of three stilbene glucosides newly extracted from Vitis vinifera cell cultures. Journal of Natural Products, Vol.61, No.5, (April 1998), pp. 655-657, ISSN 0163-3864

van Der Heijden, R.; Jacobs, DI.; Snoeijer, W.; Hallard, D. \& Verpoorte, R. (2004). The Catharanthus alkaloids: pharmacognosy and biotechnology. Current Medicinal Chemistry, Vol.11, No.5, (March 2004), pp. 607-628, ISSN 0929-8673

Vasconsuelo, A. \& Boland, R. (2007). Molecular aspects of the early stages of elicitation of secondary metabolites in plants. Plant Science, Vol.172, No.5, (May 2007), pp. 861875, ISSN 0168-9452

Versari, A.; Parpinello, GP.; Tornielli, GB.; Ferrarini, R. \& Giulivo, C. (2001). Stilbene compounds and stilbene synthase expression during ripening, wilting, and UV treatment in grape cv. Corvina. Journal of Agricultural and Food Chemistry, Vol.49, No.11, (October 2001), pp. 5531-5536, ISSN 0021-8561

Wang, JW. \& Wu. JY. (2005). Nitric oxide is involved in methyl jasmonate induced defense responses and secondary metabolism activities of Taxus cells. Plant and Cell Physiology, Vol.46, No 6, (June 2005), pp. 923-930, ISSN 0032-0781.

Wink, M. (2003). Evolution of secondary metabolites from an ecological and molecular phylogenetic perspective. Phytochemistry, Vol.64, No.1, (September 2003), pp. 3-19, ISSN 0031-9422

Wink, M. (2008). Plant secondary metabolism: Diversity, function and its evolution. Natural Products Communications, Vol.3, No.8, pp. 1205-1216, ISSN 1934-578X

Woyengo, TA.; Ramprasath, VR. \& Jones, PJH. (2009). Anticancer effects of phytosterols. European Journal of Clinical Nutrition, Vol.63, (June 2009), pp. 813-820, ISSN 09543007

Yang, RL.; Yan, ZH. \& Lu, Y. (2008). Cytotoxic Phenylpropanoids from Carrot. Journal of Agricultural and Food Chemistry, Vol.56, No.9, (April 2008), pp. 3024-3027, ISSN 0021-8561

Yukimune, Y.; Tabata, H.; Higashi, Y. \& Hara, Y. (1996). Methyl jasmonate-induced overproduction of paclitaxel and baccatin III in Taxus cell suspension cultures. Nature Biotechnology, Vol.14, No.9, (September 1996), pp. 1129-1132, ISSN 1087-0156

Zamboni, A.; Gatto, P.; Cestaro, A.; Pilati, S.; Viola, R.; Mattivi, F.; Moser, C. \& Velasco, R. (2009). Grapevine cell early activation of specific responses to DIMEB, a resveratrol elicitor. BMC Genomics, Vol.10, No.363, (August 2009), pp 1-13, ISSN 1471-2164

Zhao, J.; Davis, LC. \& Verpoorte, R. (2005). Elicitor signal transduction leading to production of plant secondary metabolites. Biotechnology Advances, Vol.23, No.4, (June 2005), pp.283-333, ISSN 0734-9750

Zhao, J.; Zhu, W. \& Hu, Q. (2001). Enhanced catharanthine production in Catharanthus roseus cell cultures by combined elicitor treatment in shake flasks and bioreactors. Enzyme and Microbial Technology, Vol.28, No.7, (May 2001), pp. 673-681, ISSN 0141-0229

Zhao, J.; Zhu, WH.; Hu, Q. \& He, XW. (2000). Improved alkaloid production in Catharanthus roseus suspension cell cultures by various chemicals. Biotechnology Letters, Vol.22, No.15, (August 2000), pp. 221-1226, ISSN 0141-5492

Zhou, ML.; Shao, JR. \& Tang, YX. (2009). Production and metabolic engineering of terpenoid indole alkaloids in cell cultures of the medicinal plant Catharanthus roseus (L.) G. Don (Madagascar periwinkle). Biotechnology and Applied Biochemistry, Vol.52, No.4, (April 2009), pp. 313-323, ISSN 0885-4513 


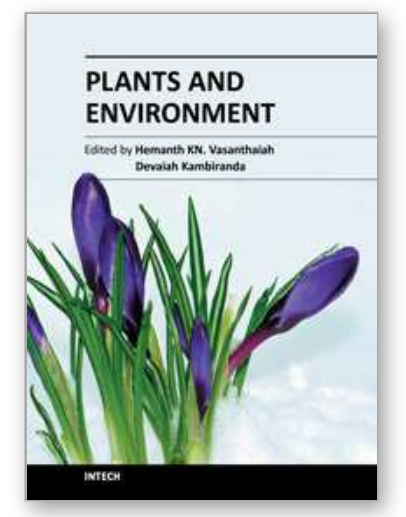

\author{
Plants and Environment \\ Edited by Dr. Hemanth Vasanthaiah
}

ISBN 978-953-307-779-6

Hard cover, 272 pages

Publisher InTech

Published online 17, October, 2011

Published in print edition October, 2011

Changing environmental condition and global population demands understanding the plant responses to hostile environment. Significant progress has been made over the past few decades through amalgamation of molecular breeding with non-conventional breeding. Understanding the cellular and molecular mechanisms to stress tolerance has received considerable scientific scrutiny because of the uniqueness of such processes to plant biology, and also its importance in the campaign â€œFreedom From Hungerâ€. The main intention of this publication is to provide a state-of-the-art and up-to-date knowledge of recent developments in understanding of plant responses to major abiotic stresses, limitations and the current status of crop improvement. A better insight will help in taking a multidisciplinary approach to address the issues affecting plant development and performance under adverse conditions. I trust this book will act as a platform to excel in the field of stress biology.

\title{
How to reference
}

In order to correctly reference this scholarly work, feel free to copy and paste the following:

Lorena Almagro, Ana Belén Sabater-Jara, Sarai Belchî-Navarro, Francisco Fernández-Pérez, Roque Bru and María A. Pedreño (2011). Effect of UV Light on Secondary Metabolite Biosynthesis in Plant Cell Cultures Elicited with Cyclodextrins and Methyl Jasmonate, Plants and Environment, Dr. Hemanth Vasanthaiah (Ed.), ISBN: 978-953-307-779-6, InTech, Available from: http://www.intechopen.com/books/plants-andenvironment/effect-of-uv-light-on-secondary-metabolite-biosynthesis-in-plant-cell-cultures-elicited-with-cyclode

\section{INTECH}

open science | open minds

\section{InTech Europe}

University Campus STeP Ri

Slavka Krautzeka 83/A

51000 Rijeka, Croatia

Phone: +385 (51) 770447

Fax: +385 (51) 686166

www.intechopen.com

\section{InTech China}

Unit 405, Office Block, Hotel Equatorial Shanghai

No.65, Yan An Road (West), Shanghai, 200040, China

中国上海市延安西路65号上海国际贵都大饭店办公楼405单元

Phone: +86-21-62489820

Fax: +86-21-62489821 
(C) 2011 The Author(s). Licensee IntechOpen. This is an open access article distributed under the terms of the Creative Commons Attribution 3.0 License, which permits unrestricted use, distribution, and reproduction in any medium, provided the original work is properly cited. 